\title{
PREVALENCE OF HYPERTENSION AMONG FULANI HERDSMEN IN RURAL COMMUNITY OF NIGERIA
}

\author{
SHAKIRAT I. BELLO ${ }^{1}$, WINIFRED A. OJIEABU ${ }^{2}$, IBRAHIM K. BELLO ${ }^{3}$
}

\begin{abstract}
Introduction:Hypertension is progressively becoming more prevalent in Nigeria. The purpose of the study was to assess the risk factors and occurrence of hypertension among Fulani herdsmen in Nigeria.

Methodology:A descriptive longitudinal study on hypertension was conducted among Fulani herdsmen residing in rural communities of Ilorin East and Moro Local Government Areas (LGAs) of Nigeria, from the age of 18 years and above. Eight hundred and seventy-two (872) consenting subjects completed a standardized questionnaire. Blood pressure, weight and height were measured and recorded using standard calibrated equipment.

Results: Of the 872 herdsmen, 351 (40.3\%) were aged 18-30 years and 632 (72.5\%) migrated from the North-West zone of Nigeria. Almost all $(n=858,98.4 \%)$ of the subjects were ignorant of hypertension. Overweight and obesity were uncommon among the subjects. The occurrence of hypertension was $17.3 \%$ with overall average systolic blood pressure (BP) of $128.8 \pm 12.3 \mathrm{mmHg}$ and diastolic BP of $84.0 \pm 8.0 \mathrm{mmHg}$. Risk factors of hypertension were types of diet [OR 0.578; 95\% confidence interval (CI) 0.113-11.418, $p<0.028$ ], smoking habit [OR 5.147; CI: 1.023-25.884, $p<$ 0.017 ] and age [OR 2.656; CI: 0.682-8.556, $p<0.031$ ].

Conclusion: Majority of hypertensive herdsmen were not aware of their status, signifying a high incidence of undiagnosed and un-controlled BP among these subjects. Public health awareness on the risk factors of hypertension is essential to reduce the burden among this population. Further research is also necessary to measure the trends of hypertension among this population
\end{abstract}

Keywords: Hypertension, Fulani herdsmen, Health awareness, Body Mass Index

\section{Introduction}

Hypertension like many other non-communicable diseases, is increasingly assuming epidemic proportion among the various populations. Hypertension affects about one billion people worldwide, causing nearly 7.1 million deaths on annual basis ${ }^{1}$. Hypertension is the most frequently encountered cardiovascular disease in Africans with congestive cardiac failure as its usual complication ${ }^{2}$. Other abnormalities are renal failure, stroke, atherosclerosis and even death ${ }^{3}$. The World Health Organization (WHO) reported that cardiovascular diseases remained prominent causes of high morbidity and mortality, in the developed countries, and is constituting a pronounced public health challenge in the developing ones ${ }^{4}$. Between the year 2000 and 2003, the overall adult occurrence of hypertension in Nigeria was $15-36.6 \% 5,6,7$. In Nigeria presently, hypertension is increasing rapidly ${ }^{8}$. A range of $13.5 \%-46.4 \%$ was observed among the rural dwellers

1. Department of Clinical Pharmacy and Pharmacy Practice, Faculty of Pharmaceutical Sciences, University of Ilorin, Ilorin, Nigeria.

2. Department of Clinical Pharmacy and Biopharmacy, Faculty of Pharmacy, OlabisiOnabanjo University, Shagamu, Nigeria.

3. Department of Pharmacy, University of Ilorin Teaching Hospital, Ilorin, Nigeria

Address of Correspondence: Shakirat I. Bello, Department of Clinical Pharmacy and Pharmacy Practice, Faculty of Pharmaceutical Sciences, University of Ilorin, Ilorin, Nigeria, E-mail: sibello10@yahoo.com

Bangladesh J Medicine 2016; 27 : 48-54 
in Nigeria ${ }^{9,10}$.Also, Omuemu ${ }^{11}$ observed $18.5 \%$ of hypertensive burden in Edo State of Nigeria. About $28.7 \%$ prevalence was reported in Ghana and $16.9 \%$ in Cameroon, $10.35 \%$ in Ethiopia while $32.6 \%$ was recorded for the blacks in the United States of America ${ }^{12,13}$. Cognizance, control and treatment of hypertension were generally low with attendant high burden and related complications. The asymptomatic nature of hypertension, environmental impact and the changing lifestyles are contributing to the increase of the disease.Oladapoet $a l^{9}$. also reported that hypertension awareness rate was $14.2 \%$ in the rural areas of Nigeria. Most people realized to be hypertensive during medical consultation ${ }^{14}$. This disease is associated with various factors, such as level of education, gender, alcohol consumption, age, smoking, obesity, genetic constitution, family history, and occupation ${ }^{15}$. However, most rural dwellers in Nigeria lack social amenities including access to health care delivery system and standard education ${ }^{16}$. Majority of rural communities consult traditional healers and private health care providers, where routine monitoring of hypertension is lacking. However, rural community-based screening for hypertension can increase the diagnosis and its treatment.

Fulani herdsmen are traditionally nomadic, pastoralist traders. They herd cattle, goats and sheep across the vast dry hinterlands. They are the largest nomadic ethnic group in the world ${ }^{17}$. The herdsmen are also found in over 26 countries within the African continent. These include Nigeria: 15.3 million, Guinea: 4.6 million, Senegal: 3.2 million, Mali: 2.5 million, Cameroon: 2.5 million, Sudan: 1.9 million, Burkina Faso: 1.7 million, Niger: 1.7 million, Mauritania: 700,000, Benin: 450,000, Guinea Bissau: 333,000, Gambia: 320,000, Sierra Leone: 310,000, Chad: 285,000 and Central African Republic: $265,000^{18}$. These herdsmen constitute the major breeders of cattle, the main source of meat; the most available and affordable source of animal proteins consumed by Nigerians ${ }^{19}$. The herdsmen were known to move from one village to another and cross many states before settling for a while, and returned back still trekking. Each return trip may last for several months and is their routine way of life. Cattle herding is a daunting task, not only toilsome, but also strenuous which may predisposedherdsmen to hypertension. Furthermore, access to healthcare facilities in their nomadic environment is lacking. Studies on occurrence and awareness of hypertension among herdsmen are limited. On this background, this study was conducted to ascertain the occurrence of hypertension and sensitize the Fulani herdsmen on the risks of the disease.

\section{Materials and Methods}

Setting of study

The capital city of Kwara State is Ilorin. It is situated $306 \mathrm{~km}$ inland from the coastal city of Lagos and 500 $\mathrm{km}$ from the Federal Capital, Abuja. There are 16 Local Government Areas (LGAs) in the State: Asa, Baruten, Edu, Ekiti, Ifelodun, Isin, Ilorin East, Ilorin South, Ilorin West, Irepodun, Kaiama, Moro, Offa, Oke-ero, Oyun and Pategi. Major towns include Offa, Omuaran and Jebba, located on the Niger River. The State has a total population of 2,591,555. The principal groups residing in Kwara State are the Yoruba, Nupe, Bariba and Fulani. Ilorin East LGA of Kwara State is located in the transitional zone between the Southern and Northern Nigeria. The twelve political wards in Ilorin East LGA are Oke-Oyi/Oke-Ose/ Alalubosa, Apado, Iponrin, Agbeyangi/Gbadamu/ Osin, Marafa/Pepele, Maya/Ile-apa, Magaji Aare I, Magaji Aare II, Sango, Ibagun, Gambari I and Gambari II. The 17 wards in Moro LGA areOkemi, Lanwa, BodeSaadu, Jebba, Okutala, Baba dudu, Ejidongari, Olooru, Shao, Pakumoh, Womi/ayaki, Malete, Arobadi, Jenkunun, Megida, Abatialaraand Ajanaku.

\section{Study population}

Ilorin East LGA has a total population of 204,310 and Moro LGA 108,792 at the year 2006 census. In the Ilorin East LGA, the 14 villages visited for the screening exercise were Woru, Agbeyangi, Lajiki, Ogele, Jolasun, Mantami, Alade, Osin-gada, Beeri, Olooro, Ajelende, Marafa, Ipako-obo and Eleja. In the Moro LGA 10 villages viz; Gbugudu, Alfa, Maraya, Saki, Baako, Eleko-yangan, GambeOko, Ogbagba, BuduOde, Olo-Ode were visited. The consented subjects in the 24 villages were enrolled for the study.

\section{Study design}

This is a rural community-based, descriptive, longitudinal research carried out among Fulani herdsmen residing in 24 villages of Moro and Ilorin East LGAs of Kwara State, in the North-Central zone of Nigeria. The study was conducted from July to October, 2015. This was the peak of rainy season with rich vegetation for the cattle to feed. At this period, Fulani herdsmen were found at their settlements. Meetings with heads of family in the communities were held to discuss the purpose of the 
study. At each settlement, those members who were eligible and consented to participate were enrolled. The eligibility criteria include male, Fulani herding, and between age of 18 years and over. Those excluded were children below the age of 18 years, women andthose who are not Fulani herdsmen.

\section{Data collection}

\section{Questionnaire}

All adults that were consented and participated in the study had their blood pressure (BP), weights and heights recorded. A pretested questionnaire was interviewer-administered to obtain information on the socio-demographic characteristics, risk factors for hypertension and history of drugs taken by the respondents. All the respondents were able to speak Hausa language and this was used as a way of communication. The questionnaire was translated to Hausa language which was validated prior to administration. Cut-off values for hypertension is defined as systolic BP e" $140 \mathrm{mmHg}$ and/or that of diastolic BP e" $90 \mathrm{mmHg}$ based on the World Health Organization guidelines of 2002, and the Seventh Joint National Committee (JNC) on Hypertension of 2003. An automated BP monitor-Model M2 basic HEM7116-E8(V) (Omron Healthcare Company Limited, Kyoto, Japan) for BP as well as calibrated Dual weight and height measuring scale-Model RGZ-160 (Medfield Medical, England) were utilized for the physical examinations of the subjects.

\section{Measurements}

Following informed verbal and written consent, the socio-demographic details of the participants were obtained. The subjects were allowed to rest for 15 minutes, and BP taken using left arm of each subject in the sitting position. BP measurements were made on three occasions per day at an interval of 5 minutes. The measurements were repeated weekly for three weeks for those subjects found to be hypertensive. The values obtained were averaged as the individual's BP. The grading systems of hypertension by JNC was followed; Normal (SBP < $120 \mathrm{mmHg}$ or DBP $80 \mathrm{mmHg}$ ); pre-hypertension (SBP 120-139 mmHg or DBP 80-89 $\mathrm{mmHg}$ ); stage 1 hypertension (SBP $140-159 \mathrm{mmHg}$ or DBP 90-99 mmHg); and stage 2 (SBP> $160 \mathrm{mmHg}$ or DBP $>100 \mathrm{mmHg}$ ). The weight and height of the patients were evaluated while standing on a calibrated Dual weight and height measuring scale. The Body Mass Index (BMI) of the subjects was computed as the weight in kilogrammes divided by the height in metre squared. The values of BMI for the subjects were grouped into four classes: Underweight/thin (BMI < $18.5 \mathrm{~kg} / \mathrm{m}^{2}$ ), normal weight (BMI 18.5-24.9kg/ $\mathrm{m}^{2}$ ), over weight (BMI 25.0-29.9 kg/m²) and obese (BMI e" 30kg/m²) 20 .

\section{Education/Counselling}

The subjects were educated on prevention, symptoms and complication of hypertension. These involve counselling of the subjects on the nature of hypertension, the advantages of BP monitoring as well as adherence to hypertensive medications. Also, lifestyle modification on diet that emphasizes eating fruits, vegetables, and low-fat dairy products, dietary sodium reduction, avoidance of alcohol consumption and smoking cessation were offered. In this study, all the subjects found to be hypertensive were referred to the nearest health institutions around the communities studied for further management.

\section{Ethical Clearance}

Ethical clearancefor the approval of this study was obtained from Kwara State Ministry of Health, Chairmen of Moro and East Ilorin LGAs of Kwara State and heads of respective rural communities.

\section{Statistical analysis}

The data collected were analyzed using Statistical Package for Social Sciences version-21 (SPSS Inc. Chicago, USA). Categorical data were expressed as frequencies, percentages and chart. Logistic regression analysis was used to assess the relationship between patient factors and hypertension. P-value of $<0.05$ was considered to be statistically significant at $95 \%$ confidence interval.

\section{Results}

Age group of 18-30 years constituted the highest number ( $\mathrm{n}=351,40.3 \%$ ) of the subjects. The average age was $39.7 \pm 2.3$ years. All the subjects $(n=872)$ were cattle herdsmen and farmers by occupation. Majority ( $\mathrm{n}=756,86.7 \%$ ) had no formal education. Almost all ( $\mathrm{n}=858,98.4 \%)$ of the subjects were ignorant of hypertension. Four hundred and five (46.4\%) earned an average income of NGN40, 000 (\$200) to NGN50, 000 (\$250) monthly through sales of farm products and cattle (Table I). Majority 846 $(97.0 \%)$ migrated from North-West zone of Nigeria to settle in Ilorin East and Moro LGAs of Kwara State (Figure I). Five hundred and eighty nine (67.5\%) were feeding on plant products(vegetarians) and the rest were on plants and animal products (non-vegetarians) (Table II). 
Table I

General characteristics of the subjects

\begin{tabular}{ccc}
\hline Parameter & Frequency & $\%$ \\
\hline Age group (years) & & \\
$18-30$ & 351 & 40.3 \\
$31-40$ & 207 & 23.7 \\
$41-50$ & 175 & 20.1 \\
$51-60$ & 89 & 10.2 \\
$60^{+}$ & 50 & 5.7
\end{tabular}

Average age

$39.7 \pm 2.3$

Occupation

Cattle rearing and farming

872

100.0

Educational Status

Illiterates

756

86.7

Quranic education

116

13.3

Language spoken

Fulfulde and Hausa

$872 \quad 100.00$

Level of Awareness of the hypertension

$\begin{array}{lcc}\text { Aware } & 14 & 1.6 \\ \text { Not aware } & 858 & 98.4\end{array}$

Income per monthly (NGN)

\begin{tabular}{ccc}
$20,000.00-30,000.00$ & 276 & 31.7 \\
$40,000.00-50,000.00$ & 405 & 46.4 \\
$50,000.00-60,000.00$ & 87 & 10.0 \\
$70,000.00-80,000.00$ & 104 & 11.9 \\
\hline
\end{tabular}

The incidence of hypertension among the subjects was $17.3 \%(n=151)$. The hypertensive subjects had both elevated systolic and the diastolic BP of moderate grade and $721(82.7 \%)$ were normotensive (Table III). The overall average BP among the subjects was 128.8

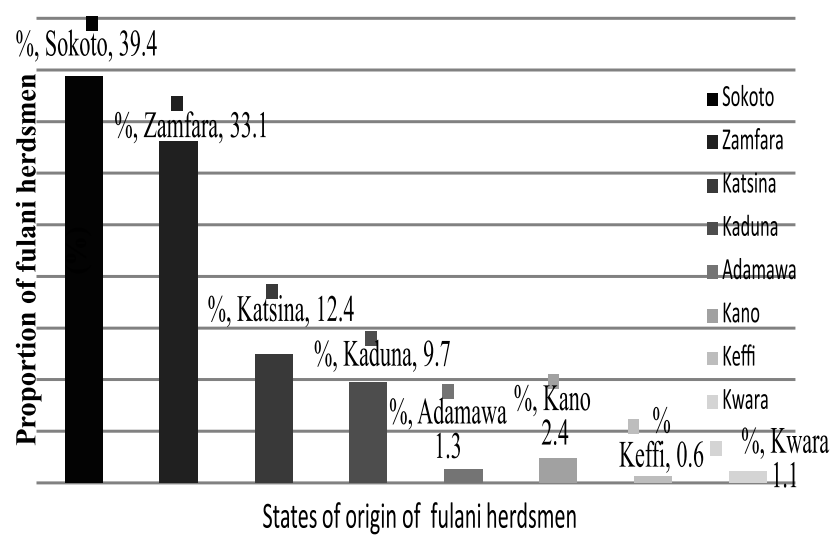

Fig.-I: Distribution of herdsmen by states origin

$\pm 12.3 \mathrm{mmHg}$ for systolic and $84.0 \pm 8.0$ for diastolic (Table IV). The increase in average diastolic and systolic blood pressures were not consistent with age, being highest in age category $18-30$ years (148.0 $\pm 10.4 / 92.0 \pm 5.3)$ and lowest in age group 51-60 years $(118.0 \pm 12.1 / 78.0 \pm 10.2)$.

Table II: Types of diets of the subjects

\begin{tabular}{lcc}
\hline Diets & Frequency & $\%$ \\
\hline $\begin{array}{l}\text { Tuwomansara + vegetable/ } \\
\text { okro/kuka soup }\end{array}$ & 474 & 54.3 \\
$\begin{array}{l}\text { Furagero + raw cow milk } \\
\text { (noonoo) }\end{array}$ & 268 & 30.7 \\
Guinea corn pap + sugar & 79 & 9.1 \\
$\begin{array}{l}\text { Rice + mai-shaanu/palm oil } \\
\text { Rice + beans + mai-shaanu }\end{array}$ & 18 & 2.1 \\
/ palm oil & 10 & 1.1 \\
$\begin{array}{l}\text { Yam + mai-shaanu/palm oil } \\
\text { Rice + beans + mai-shaanu+ } \\
\text { meat + egg }\end{array}$ & 8 & 0.9 \\
$\begin{array}{l}\text { Yam + mai-shaanu/palm oil + } \\
\text { chicken + fish }\end{array}$ & 6 & 1.1 \\
\hline
\end{tabular}

Table III

JNC Classification of hypertension

\begin{tabular}{lcc}
\hline $\mathrm{BP}(\mathrm{mmHg})$ & Frequency & $\%$ \\
\hline Normal ( SBP $<120$ or DBP< 80) & 721 & 82.7 \\
Pre-hypertension(SBP120-139 or DBP 80-89) & 0 & 0 \\
Stage 1 hypertension (SBP140-159 or DBP 90-99) & 151 & 17.3 \\
Stage 2 hypertension (SBP> 160 or DBP>100) & 0 & 0 \\
\hline
\end{tabular}


Table IV

Age distribution of subjects with hypertension

\begin{tabular}{lcc}
\hline Age group (years) & $\begin{array}{c}\text { SBP }(\mathrm{mmHg}) \\
\text { Average } \pm \text { SD }\end{array}$ & $\begin{array}{c}\text { DBP }(\mathrm{mmHg}) \\
\text { Average } \pm \text { SD }\end{array}$ \\
\hline $18-30$ & $148.0 \pm 10.4$ & $92.0 \pm 5.7$ \\
$31-40$ & $119.0 \pm 13.7$ & $80.0 \pm 8.3$ \\
$41-50$ & $140.0 \pm 11.3$ & $91.0 \pm 6.8$ \\
$51-60$ & $118.0 \pm 12.1$ & $78.0 \pm 10.2$ \\
$60+$ & $119.0 \pm 13.9$ & $79.0 \pm 9.1$ \\
Overall average & $128.8 \pm 12.3$ & $84.0 \pm 8.0$ \\
F-value & 7.324 & 8.445 \\
P-value & 0.007 & 0.033 \\
\hline
\end{tabular}

Types of diet [OR 0.578; 95\% confidence interval (CI) $0.113-11.418, \mathrm{p}<0.028$ ], smoking habit [OR 5.147; 95\% confidence interval (CI) 1.023-25.884, $\mathrm{p}<0.017]$ and age[OR 2.656; 95\% confidence interval (CI) 0.6828.556, $\mathrm{p}<0.031$ ] were found to be significant predictors of hypertension among Fulani herdsmen (Table V).

\section{Table V}

Logistic regression analysis of predictors of hypertension among Fulani herdsmen

\begin{tabular}{|c|c|c|c|c|}
\hline \multirow[t]{2}{*}{ Parameters } & \multirow{2}{*}{$\begin{array}{c}\mathrm{p}- \\
\text { value }\end{array}$} & \multicolumn{2}{|c|}{ Odd95\% C.I for } & \multirow{2}{*}{$\begin{array}{c}\text { Odd Ratio } \\
\text { Upper }\end{array}$} \\
\hline & & tio (OR) & Lower & \\
\hline \multicolumn{5}{|l|}{ Age (Years) } \\
\hline $18-30$ & $0.031 *$ & 2.656 & 0.682 & 8.556 \\
\hline $31-40$ & 0.442 & 0.312 & 0.367 & 9.927 \\
\hline $41-50$ & 0.265 & 1.910 & 0.447 & 14.789 \\
\hline $51-60$ & 0.567 & 0.413 & 0.097 & 1.464 \\
\hline $60^{+}$ & 0.742 & 1.000 & 0.504 & 4.122 \\
\hline \multicolumn{5}{|c|}{ Body Mass Index $\left(\mathrm{Kg} / \mathrm{m}^{2}\right)$} \\
\hline$<18.5$ (low) & 0.153 & 0.873 & 0.979 & 1.069 \\
\hline $18.5-24.9$ & 0.998 & 1.000 & 0.123 & 3.145 \\
\hline \multicolumn{5}{|l|}{ (normal) } \\
\hline \multicolumn{5}{|c|}{ Alcohol Consumption } \\
\hline Present & 0.493 & 1.585 & 0.123 & 3.145 \\
\hline Absent & 0.284 & 1.000 & 0.504 & 10.357 \\
\hline \multicolumn{5}{|c|}{ Smoking Habit } \\
\hline Present & $0.017 *$ & 5.147 & 1.023 & 25.884 \\
\hline Absent & 0.265 & 1.000 & 1.234 & 7.134 \\
\hline \multicolumn{5}{|c|}{ Types of Diet } \\
\hline Vegetarian & $0.028 *$ & 0.578 & 0.113 & 11.418 \\
\hline \multicolumn{2}{|c|}{ Lacto-vegetarian 0.430} & 1.000 & 0.150 & 86.261 \\
\hline
\end{tabular}

* Statistically significant at $\mathrm{P}<0.05$

\section{Discussion}

The occurrence of hypertension among the herdsmen screened was $17.3 \%$. This was in agreement with the previous studies of Cooper et $a l^{21}$ in Cameroon (16.9\%), Yuvarajet $\mathrm{al}^{22}$ in rural communities of India (18.3\%) and Oladapoet $\mathrm{al}^{9}$. (2010 9) $(20.8 \%)$ in Nigeria. The findings of Cappuccioet $a l^{23}$ in Ghana with occurrence of $(28.7 \%)$, Wamala et $a l^{24}$ in Uganda (30.5\%) and Adedoyinet $\mathrm{al}^{7}$ in Nigeria (36.6\%) were higher than the result of this study (17.3\%). In a few of the studies, especially in the Eastern part of the country, hypertension was found to be as high in the rural populace compared to the urban ${ }^{25}$. This picture has been documented in some United States and European studies $26,27$.

The average age of the subjects studied was 39.0 years. This was lower as compared to the findings of AsekunOlarinmoyeet $a^{28}$ in Osun State, Nigeria who reported average age of about 49 years. However, this was comparable to the study of Addoet $\mathrm{al}^{29}$ in Ghana with average age of 42 years among the rural communities. One third of the subjects with hypertension were within the age category of 18-30 years. The present work was inconsistent with the findings of Ogahet $a l^{10}$ who reported high incidence of hypertension among oldest age brackets. The rationale for the higher prevalence of hypertension in Fulani youths could be that the strenuous cattle herding is dominated by them. While herding, these youths leave the bush to the cities to search for food and veterinary drugs for their cattle. At this period, they feed on fatty meals (such as meat, eggs, chicken), smoked cannabis and consumed hard drugs which are risk factors for hypertension apart from the inherent stress of the herding process.

In the present study, there was an increase in both diastolic and systolic blood pressures among Fulani herdsmen. This was unlike the results of $\mathrm{Abu}$ Sayeedet $\mathrm{al}^{30}$ in Bangladesh and Asekun-Olarinmoyeet $a l^{28}$ in Nigeria. Also, this study was inconsistent with that of Glewet $a l^{31}$ in Nigeria where the normal average BP of $120 / 74 \mathrm{mmHg}$ was observed from the herdsmen. Moderate hypertension was found in the subjects studied, unlike the studies of Oladapoet ${ }^{9}{ }^{9}$. who reported both mild and moderate hypertension. High occurrence of hypertension among the youths observed in this study may be due to low level of education, poor awareness of hypertension and inaccessibility to healthcare facilities. These probably resulted to high sodium chloride intake, seasoning cubes in soups, daily consumption of saturated fatty milk (raw cow milk and mai-shaanu) and alcohol consumption, smoking of hard drugs, and abuse of 
drugs containing caffeine. These results were similar to the studies of Kapooret $\mathrm{al}^{15}$ in India who observed hypertension to be associated with various factors, such as family history, age, gender, smoking, obesity, alcohol consumption, occupation and level of education. In addition, Doleaet $a l^{16}$ reported that bulks of rural populace in Nigeria were marginalized with inadequate access to quality education and health care. A significant number of herdsmen seek medical consultations from traditional healers where improper examinations of hypertension were conducted. They consulted traditional herbalists called Booka (who use glass and sand as means of diagnosis).

Hypertension and other chronic diseases' awareness, treatment and control are low in developing countries including Nigeria. These diseases are often asymptomatic and in most cases presentation is when complications have set in $^{32}$. This study discovered that only $1.6 \%$ of the subjects were aware of hypertension and the information was obtained through relatives receiving treatment on hypertension. In this study, the diet of the subjects was significantly associated with hypertension. Only $12.4 \%$ of the vegetarians had hypertension while $31.4 \%$ were hypertensive among the lacto-vegetarians. This corroborates with the study of Ophiret $\mathrm{al}^{33}$ in Israel whereby $2 \%$ of vegetarians had hypertension as compared to $26 \%$ in the lacto-vegetarians. This was unlike the previous study of Mahmoodet $a l^{34}$ who reported that type of diets (vegetarians versus lactovegetarians) were not found to be significantly associated with hypertension. In the present work, there was a significant association between hypertension and smoking. This was in line with the findings of Tiwari ${ }^{35}$ who reported that smokers have a significantly higher BP than non-smokers, but inconsistent with the results of Mahmoodet $\mathrm{al}^{34}$. This study revealed that BMI was not significantly associated with hypertension. This study was contrary to the findings of Agyemanget $a l^{36}$ whereby BMI is strongly correlated with diastolic and systolic BP. Unlike the findings of Amoah ${ }^{37}$ who reported that obesity and overweight were prevalence in the rural communities in Nigeria, none of the subjects in this study were obese or overweight. Ogahet $\mathrm{al}^{10}$ reported that obesity was higher in urban areas than in rural areas because of reduced physical activity and the likelihood to eat processed foods which are high in salt and fat contents.

\section{Conclusion}

Majority of hypertensive herdsmen were not aware of their status, signifying a high incidence of un- diagnosed and un-controlled BP among these subjects.Public health education and intensification of awareness of hypertension and its consequences could reduce morbidity and mortality. Also, further research needs to be conducted to measure trends of hypertension among these subjects.

\section{References}

1. Brundtland, GH.From the World Health Organization: Reducing risks to health, promoting healthy life. JAMA2002;288:19-24.

2. Akinkugbe, OO. World epidemiology of hypertension in blacks. In: Hall WD, Saunders, E, and Shulman, NB., editors, 1985.Hypertension in Blacks. Philadelphia, PA: ChicagoYear Book Publishers.

3. Bloch, MJ and Basile, JN. Hypertension in the elderly. In: Black HR, Elliot WJ, editors. Hypertension: A Companion to Braunwald's Heart Disease, 1st ed. 2007.Philadelphia, PA: Saunders.

4. Mukadas, AO. and Misbau, U. Incidence and patterns of cardiovascular disease in NorthWestern Nigeria. Nigerian Medical Journal2009;50:55-57.

5. Akinkugbe, OO. Current epidemiology of hypertension in Nigeria. Archives of Ibadan Medicine2000;19:1-3.

6. Kadiri, S. Tracking cardiovascular disease in Africa. BMJ2005; 331:711-712.

7. Adedoyin, RA, Mbada, CE, Balogun, MO. et al. Occurrence and pattern of hypertension in a semiurban community in Nigeria. European Journal of Cardiovascular Prevention and Rehabilitation2008;15:683-687.

8. Egbi, OG, Okafor, UH, Meibodei, KE, Kunle-Olowu, $\mathrm{OE}$ and Unuigbe, EI. Prevalence of hypertension in an urban population in Bayelsa State, Nigeria.Journal of Medical Research and Practices 2013; 2(1):12-15.

9. Oladapo, OO, Salako, L, Sodiq, O, Shoyinka, K, Adedapo, K, Falase, AO. A occurrence of cardiometabolic risk factors among a rural Yoruba South-Western Nigerian population: A population based survey. Cardiovascular Journal of Africa2010;21:26-31.

10. Ogah, OS, Okpechil, Chukwuonye, II, Akinyemi, JO, Onwubere, BJC, Falase, AO, Stewart, S and Sliwa, K. Blood pressure, occurrence of hypertension and hypertension related complications in Nigerian Africans: A Review World Journal of Cardiology2012; 4(12):327-340.

11. Omuemu, VO, Okojie, $\mathrm{OH}$ and Omuemu, CE. Awareness of high blood pressure status, treatment and control in a rural community in Edo State. Nigerian Journal of Clinical Practice 2007;10:20812 . 
12. Amoah, GB.Hypertension in Ghana: A crosssectional community occurrence study in Greater Accra. Ethnicity and Disease2003a;13:310-315.

13. Ogah, OS, OkpechiI, Chukwuonye, II, Akinyemi, JO, Onwubere, BJC, Falase, AO, Stewart, S and Sliwa, K. Blood pressure, occurrence of hypertension and hypertension related complications in Nigerian Africans: A Review World Journal of Cardiology2012;4(12):327-340.

14. Ayodele, OE, Alebiosu, CO, Akinwusi, PO, Akinsola, A, Mejuini, A. Target organ damage and associated clinical conditions in newly diagnosed hypertensive attending a tertiary health facility. Nigerian Journal of Clinical Practice2007;10:319-325.

15. Kapoor, S, Tyagi, R, Saluja, K, Chaturvedi, A, Kapoor, AK. Emerging health threats among a primitive tribal group of Central India. Journal of Public Health and Epidemiology 2010;2:13-19.

16. Dolea, C, Stormont, L and Braicheta, JM.Evaluated strategies to increase attraction and retention of health workers in remote and rural areas. Bulletine of World Health Organization2010;88:379-385.

17. AllAfrica.com. NigeriaGoing Beyond the Green Wall Ritual. Retrieved 2016-02-27. http://allafrica.com/ stories/201307041283.html. 2013.

18. Itua, F. Outrage over activities of Fulani herdsmen. Available at: http://sunnewsonline.com/new/ outrage-activities-fulani-herdsmen [Accessed on 1902-2016]. 2013.

19. Fabusoro, E. Key issues in livelihoods security of migrant Fulani pastoralists: Empirical evidence from Southwest Nigeria. AIGIS European Conference on African Studies-African Alternatives: Initiative Current Constraints-African Studies Centre, Leiden, The Netherlands. 2007.

20. World Health Organization. Obesity: Preventing and managing the global epidemic.WHO, Geneva.1997:35 .

21. Cooper, R, Rotimi, C, Ataman, S, McGee, D, Osotimehin, B, Kadiri, S, Muna, W, Kingue, S, Fraser, H, Forrester, T, Bennett, FandWilks, R. The prevalence of hypertension in seven populations of West African origin. American Journal of Public Health1997;87:160-168.

22. Yuvaraj, BY, Nagendra, GMR. andUmakantha, AG. Prevalence, awareness, treatment, and control of hypertension in rural areas of Davanagere. Indian Journal of Community Medicine2010; 35:138-141.

23. Cappuccio, FP, Micah, FB, Lynsey, E, et al. Prevalence, detection, management, andcontrol of hypertension in Ashanti, West Africa. Hypertension2004;43:1017-1022.

24. Wamala, JF, Karyabakabo, Z, Ndungutse, D and Guwatudde, DPrevalence factorsassociated with hypertension in Rukungiri District, Uganda: A community-based study. African Health Sciences2009;9(3):153-160.

25. Ahaneku, GI, Osuji, CU, Anisiuba, BC, Ikeh, VO, Oguejiofor, OC. and Ahaneku, JE. Evaluation of $\mathrm{BP}$ and indices of obesity in a typical rural community in eastern Nigeria. Annals of African Medicine2011;10:120-126.

26. Mainous, AG, King, DE, Garr, DR and Pearson, WS.Race, rural residence, and control of diabetes and hypertension. Annals of Family Medicine 2004: 2:563-568.

27. Psaltopoulou, T, Orfanos, P, Naska, A, Lenas, D, Trichopoulos, D and Trichopoulou, A. Occurrence, awareness, treatment and control of hypertension in a general population sample of 26,913 adults in the Greek EPIC study. International Journal of Epidemiology 2004;33:1345-1352.

28. Asekun-Olarinmoye, EO, Akinwusi, PO, Adebimpe, WO.,Isawumi, MA., Hassan, MB, Olowe, OA, Makanjuola, OB, Alebiosu, CO. and Adewole, TA.Occurrence of hypertension in the rural adult population of Osun State, Southwestern Nigeria. International Journal of General Medicine2013;6:317322 .

29. Addo, J, Amoah, GB. andKoram, KA. The changing patterns of hypertension in Ghana: A study of four rural communities in the Ga district. Ethnicity and Disease2006;16: 894-899.

30. Abu Sayeed, M, Banu, A, Khan, AR and Hussain, MZ. Prevalence of diabetes andhypertension in a rural population of Bangladesh. Diabetes Care, 1995; 18(4):555-558.

31. Glew, RH, Kassam, HA, Bhanji, RA, Okorodudu, A and Vanderjagt, DJ. Serum lipid profiles and risk of cardiovascular disease in three different male populations in Northern Nigeria. Journal of Health Population and Nutrition2002;20(2):166-174.

32. Ogah, OS. Hypertension in Sub-saharan African populations: The burden of hypertension in Nigeria. Ethnicity and Disease 2006;16:765.

33. Ophir, O, Gilad, PG, Blum, JM and Aviram, A. Low blood pressure in vegetarians: the possible role of potassium. The American Journal of Clinical Nutrition 1983; 37,755-762.

34. Mahmood, SE, Srivastava, A, Shrotriya, VP, Shaifali, I, Mishra, P. Occurrence andepidemiological correlates of hypertension among labour population. National Journal of Community Medicine 2011; 2(1):43-48.

35. Tiwari, RR. Hypertension and epidemiological factors among tribal labour population in Gujarat. Indian Journal of Public Health2008;52(3):144-146.

36. Agyemang, C. Rural and urban differences in BP and hypertension in Ghana, West Africa. Public Health2006:120;525-533.

37. Amoah, A.G. (2003b). Socio-demographic variations in obesity among Ghanaian adults. Public Health Nutrition, 6, 751-757. 